\title{
MAJORITY RULE, EXCLUSIVE REPRESENTATION, AND THE INTERESTS OF INDIVIDUAL WORKERS: SHOULD EXCLUSIVITY BE ABOLISHED?
}

\section{George Schatzki $\dagger$}

Under the Taft-Hartley (nee Wagner) Act, the National Labor Relations Board is authorized to conduct elections among groups of employees to determine whether a union, by obtaining a majority vote, shall be the exclusive representative of any given group of employees for the purposes of collective bargaining with their employer. ${ }^{1}$ In addition, the Act has been interpreted to permit, or even require, an employer to recognize a union as the exclusive bargaining representative of a group of its employees without an election if it is established, first, that the union was selected by a majority of those employees to be represented, ${ }^{2}$ and second, that the employer's antiunion conduct made a fair election improbable. Implicit in all of this, and explicit in section 9 of the Act, is the necessity to determine the "appropriate unit" for these purposes. Since the Act only requires a majority, and not unanimity, the Board is not charged to determine what each individual employee believes or desires to be the appropriate unit; and the Board does not consult the employees or attempt to ascertain their wishes. Rather, the Board looks to many "objective" factors in any given case to make the determination. While some of the factors may indirectly reflect individual employee preferences, and while much of the Board rhetoric in defining the appropriate unit is about the community of interests among the employees, ${ }^{3}$ in truth most of the

$\dagger$ Professor of Law, University of Texas at Austin.

129 U.S.C. $\$ 159$ (a) (1970).

${ }^{2}$ Linden Lumber Div., Summer \& Co. v. NLRB, 95 S. Ct. 429 (1974); NLRB v. Gissel Packing Co., 395 U.S. 575 (1969).

${ }^{3}$ E.g., Bomber Bait Co., 85 L.R.R.M. 1125, 1125-26 (1973): "In view of the record evidence which establishes that the homeworkers and the plant employees share a community of interest, and in view of the agreement of the parties to include these employees in the same unit which is not contrary to Board policy, there is no basis for failing to include homeworkers in an overall production and maintenance unit." It is worth noting that while the rhetoric is to "community of interest," 
factors which go into determining the unit reflect either the structure the employer has given its business, ${ }^{4}$ or the wishes of the petitioning labor organization, ${ }^{5}$ or both. Thus, employees' interests are usually not relevant to the identification of the appropriate unit's profile. The Board assumes that there is-or is not-a community of interests among certain employees, but a conclusion on this issue does not reflect or have any relationship to the individual employees' own views of their community of interests. The determining factor is the Board's view of what ought to be, or might be, or is, a community of interests among employees. One can guess that consistency of the Board's conclusions with employees' choices of who should be in the same unit is mere happenstance.

In addition, as already pointed out, as many as one less than half the employees in a designated unit may have a collective bargaining representative imposed upon them which they not only did not want, but which they consistently and vigorously opposed. The union which is designated by a majority of the relevant employees not only negotiates collective bargaining contracts on behalf of the employees who opposed it, but is also the exclusive agent of those opposition employees in settling their individual grievances with the employer.

The purposes of this Article are, first, to explore the apparent consequences of the doctrine of exclusive representation, and second, to ask whether the federal labor laws would do better by abandoning the doctrine.

\section{Current Labor Relations Law and the INDIVIDUAL WORKER}

Generally, individual interests have received short shrift under the National Labor Relations Act in a variety of contexts. ${ }^{6}$

the fact that the employer and the union wanted the unit may have been the true determinant in this case. Moreover, a close reading of the cases show's that "community of interest" is defined by job conditions imposed by the employer.

'E.g., Continental Baking Co., 99 N.L.R.B. 777, 778 (1952). "First and foremost is the principle that mutuality of interests in wages, hours, and working conditions is the prime determinant of whether a given group of employees constitutes an appropriate bargaining unit." Note that lip service is paid "mutuality of interests" of employees, but the real factors for decision are the conditions of employment set by the employer.

s Section 9(c)(5), 29 U.S.C. $\S 159(c)(5)$ (1970), precludes the extent of union organizational activity from being "controlling," but union desires have an enormous impact on the Board's determination of the appropriate unit. See NLRB v. Metropolitan Life Ins. Co., 380 U.S. 438 (1965).

${ }^{6}$ For fear of being identified as a polemicist, I should make clear that the Board 
As described above, only lip service is paid to individual interests in the unit determination process; in fact, those interests are consistently overwhelmed by other considerations. In other contexts, lip service-at best-is the only recognition given individual interests as the Act is usually (perhaps, always) interpreted.

For example, in Exchange Parts, ${ }^{7}$ the employer improved the employees' working conditions shortly before an NLRB-conducted election. As a result, it was assumed by the Board, the union lost the election. Since the union challenged the election for this reason, the Board had to determine whether the employer's behavior constituted improper interference with the conduct of a fair election. The Board held the employer's acts unlawful; the Supreme Court agreed. In neither the Board's nor the Supreme Court's opinion is there recognition of the fact that to set aside the election and order the unilateral changes rescinded would deny the employees what it was they desired.

In Darlington, ${ }^{8}$ the Supreme Court held that section 8(a)(3) does not protect employees who join unions; the Act protects only employees in thinking or talking about joining unions. The statute outlaws employment discrimination which discourages union membership (does loss of employment for designating a union qualify?). The Court concluded that the Act protects only nonexistent employees in a case in which the employer went completely out of business and that there could therefore be no violation in such a case (even though this meant all the employees lost their jobs because a majority of them engaged in union activity). ${ }^{9}$

and the Supreme Court have not universally ignored individual employees' interests when those interests interfered with other interests. See, e.g., NLRB v. Magnavox Co., 415 U.S. 322 (1974) (employer cannot enforce a collective bargaining contract against individual employees who violate provision forbidding distribution of union literature during nonworking time in nonworking areas by soliciting for a union other than the one that currently represented the employees); NLRB v. Washington Aluminum Co., 370 U.S. 9 (1962) (unrepresented employees who engage in concerted walkout, arguably without notice or explanation to the employer, are protected by the Act); and Steele v. Louisville \& N.R.R., 323 U.S. 192 (1944) (exclusive bargaining representative is liable to employees who are subjected to inferior representation based on their race). However, it is not unfair to state that usually, if not always, the resolution of conflicting interests has been against individual interests if any reasonable case could be made for that conclusion, regardless of the opportunity for an equally or more reasonable resolution in favor of individual interests.

${ }^{7}$ Exchange Parts Co., 131 N.L.R.B. 806 (1961), enforcement denied, 304 F.2d 368 (5th Cir. 1962), rev'd, 375 U.S. 405 (1964).

${ }^{8}$ Textile Workers Union v. Darlington Mfg. Co., 380 U.S. 263 (1965).

"In Darlington, the Court was not clear whether the employer had ceased to exist entirely. Accordingly, the case was remanded to determine whether there were any 
In a series of cases decided under sections $8(a)(1)$ and (3), the Supreme Court has given very narrow scope to section 7's promise of protection to employees in the exercise of concerted activities for better working conditions. ${ }^{10}$ Having been reversed many times over the years, the Board has accepted such a narrow reading of the Act's protective provisions. ${ }^{11}$ As a result, employees may be discharged for slowdowns, quickie strikes, wildcat activities, strikes in breach of collective bargaining contracts, activities which constitute part of a labor organization's violation of the Act, and activities which violate other laws. ${ }^{12}$ In

surviving employees who were intimidated by the employer's termination of the employees who selected a union.

${ }_{10}$ Emporium Capwell Co. v. Western Addition Commun. Org., 95 S. Ct. 977 (1975) (wildcat strike to protest alleged racial discrimination is unprotected); NLRB v. Local 1229, IBEW, 346 U.S. 464 (1953) (the Act does not protect striking employees who publicly disparage the product those employees helped to "foist" on the public); NLRB v. Rockaway News Supply Co., 345 U.S. 71 (1953) (employee who refuses to cross a picket line is lawfully discharged where contract outlaws strikes and arbitrator interprets the contract to include a bar on employees' honoring picket lines, although contract did not specifically mention the subject); Local 232, UAW v. Wisconsin Employment Relations Bd., 336 U.S. 245 (1949) (unannounced "quickie" strikes are not protected by the federal Act; therefore, the states can regulate such conduct); Southern S.S. Co. v. NLRB, 316 U.S. 31 (1942) (employees who strike in violation of the mutiny laws of the United States are not protected by $\S 7$ of the Act, even if the interpretation of the Mutiny Act which makes the strike unlawful was not clear or hardly predictable at the time of the employees' conduct. In this case, as well as Fansteel and others, it seems not to matter that the strike was conducted with the apparent authority of the union; the employees still lose their jobs); NLRB v. Sands Mfg. Co., 306 U.S. 332 (1939) (usually cited for the proposition that strikes in breach of contract are unprotected by the Act); NLRB v. Fansteel Metallurgical Corp., 306 U.S. 240 (1939) (although punished by civil authorities, employees who engaged in a sitdown strike are not protected by the Act, regardless of employer's unlawful conduct which provoked the employees' activities). But see NLRB v. Washington Aluminum Co., 370 U.S. 9 (1962) (strike without forewarning by unorganized employees to protest cold working conditions is protected by the Act); Mastro Plastics Corp. v. NLRB, 350 U.S. 270 (1956) (strike in protest of flagrant employer unfair labor practices is protected activity in the face of a general no-strike clause and despite the fact it occurred during the statutory period provided by $\S 8(\mathrm{~d})(4)$ of the $A c t)$.

"See, e.g., Fort Smith Chair Co., 143 N.L.R.B. 514 (1963) (union failed to notify the federal mediation and conciliation service as required by $\S 8(\mathrm{~d})(3)$; accordingly, the strikers were unprotected and were lawfully discharged); Elk Lumber Co., 91 N.L.R.B. 333 (1950) (slowdown to attain higher wages is unprotected activity); Thompson Products, Inc., 72 N.L.R.B. 886 (1947) (employer did not violate the Act by discharging employees who struck to compel employer to recognize a union after the Board had certified another union). Still, over the years, the Board has not been entirely convinced by the Supreme Court's attitudes. See, e.g., National Packing Co., 147 N.L.R.B. 446 (1964), enforcement denied, 352 F.2d 482 (10th Cir. 1965), on remand, 158 N.L.R.B. 1680 (1966), enforcement denied, 377 F.2d 800 (10th Cir. 1967); Dobbs Houses, Inc., 135 N.L.R.B. 885 (1962), enforcement denied, 325 F.2d 531 (5th Cir. 1963); Hoover Co., 90 N.L.R.B. 1614 (1950), enforcement denied, 191 F.2d 380 (6th Cir. 1951).

${ }^{12}$ Ser note 10 supra. 
addition to the obvious and severe impact of these cases on the often helpless individual employees, the effect of this narrow interpretation of section 7 is to place restrictions on unions' ability to exert economic pressure upon employers. Often-if not usually-employees engaged in concerted activities for the betterment of their wages, hours, and other conditions of employment are acting at the behest of, or in league with, their collective bargaining agent.

A fallout, or unintended, consequence of having stripped unions of considerable power by this strict construction of the Act may have been a tendency to balance things by giving unions greater strength in other areas than otherwise would be justified. These areas may be, unfortunately, also contexts in which the individual workers pay the major price, rather than the unions being repaid for the loss of their economic strength by interpretations of the Act which would come out of the employers' hides. It is ironic, and perhaps cruel as well, that the employees are the primary victims in an effort to keep employers strong vis-à-vis unions, and that employees are similarly victimized to keep unions strong vis-à-vis employers.

Much of what follows are examples of keeping unions strong. Exclusive representation appears often, if not always, to be the doctrinal cause or justification. While I have made no exhaustive effort to explore the various problems, I do attempt to suggest some better ways to deal with the issues.

\section{A. Fair Representation}

It is often said that a union, in the representation of employees, should be analogized to a legislature in its representation of all persons. ${ }^{13}$ Like the legislature, the union has been selected by a majority; and like the legislature, it will participate in the creation of laws which will affect all, even those who did not want it to represent them in the first place. To that point, the analogy appears to have some merit, although it is unduly simple and somewhat deceptive. It should not be pushed too far. For example, the union does not decide unilaterally what the new "legislation" will be; the employer must participate and, indeed, in a very real sense remains the one to call the tune. As antiunion employers are fond of pointing out in election cam-

13 "For the [bargaining] representative is clothed with power not unlike that of a legislature . . ." Steel v. Louisville \& N.R.R., 323 U.S. 192, 198 (1944). 
paigns, only the employer can put a raise in the employees' pay envelope. And, at least after giving collective bargaining a try, an employer may be able to put that pay increase into the envelope even without the union's agreement. ${ }^{14}$ While a legislature passes laws which deal with all walks of life, rarely does it deal with issues of intense and direct interest and effect to all the electorate. Unions do this all the time in reaching agreements with employers about wages, hours, and other terms and conditions of employment.

Moreover, in our society neither the legislature nor its agents represent all people in their individual concerns or grievances with others. Quite to the contrary, people select their own representatives to help in settling individually identifiable interests. Unions, on the other hand, represent all employees in their individual grievances, including the complaints of employees who actively oppose the union or its leadership.

Thus, one can question whether the analogy to the legislature is very useful when dealing with the obligation owed by the union to all the individuals it represents. While it is true the individuals often will have conflicting interests which may be irreconcilable, and that someone has to resolve the competing interests, one may be compelled to conclude that close supervision of the resolver is in order, especially when the decisionmaker is an exclusive representative chosen by the majority. This should be clear because the union is not neutral, but is controlled by one employee group or another from among the conflicting interests. It is from this concern, with a possible constitutional basis as well, that the duty to represent all the employees in the unit, the duty of fair representation, found and still finds its bottom. ${ }^{15}$

Given the conflicting interests of the many employees in a unit and the expertise of the union, the courts are prepared to defer to the unions' judgment, in most cases, of what cause is best for the most employees. Accordingly, the Supreme Court has told us that the duty of fair representation requires only that the union refrain from acting "arbitrar[il]y, discriminator[il]y or in bad faith."16 It is not clear to what extent the duty

${ }^{14}$ See, e.g., NLRB v. Crompton-Highland Mills, Inc., 337 U.S. 217, 225 (1949);

NLRB v. U.S. Sonics Corp., 312 F.2d 610 (1st Cir. 1963).

${ }^{15}$ See Steele v. Louisville \& N.R.R., 323 U.S. 192 (1944).

16 Vaca v. Sipes, 383 U.S. 171, 190 (1967). 
outlaws union discriminatory activity based on what are arguably irrelevancies to the union's accepted role, ${ }^{17}$ nor whether violation of the duty requires that the union act intentionally to deprive the employee of something he or she has a right to have. ${ }^{18}$ Perhaps time will make clearer what the duty implies. In the meantime, it does appear that the doctrine is to be construed narrowly. ${ }^{19}$

What is clear, however, is that the concept of fair representation, whatever it means, is a necessary implication of the Act because of one idea in particular: the doctrine of exclusive representation. Without that doctrine, employees would be free to select their representatives without being subjected to a political majority which is unsympathetic to the minority's desires. While I am not so naive as to believe that all conflicts between employees and their representatives would disappear if only exclusivity were jettisoned, conflicts created by individuals' need for fair treatment at the hands of their union could be greatly reduced if exclusivity were abandoned and employees were allowed to be represented by their own individually chosen agents.

Whatever can be said for sacrificing the minority's interests for the good of all, or at least for the majority, the idea makes no sense when the issue is what should be done regarding a single individual's grievance with his or her employer. No longer can it be said that the union is acting like a legislature. In this context, the union is the representative of the individual; it does not suffice to say that even in this context the union must first think of and consider the interests of the majority, or consider what is the best for the most, or that the union must consider as paramount the "proper" interpretation of the collective bar-

${ }^{17}$ The Court said in Steele itself that union discrimination within the bargaining unit could not be "irrelevant and invidious." 323 U.S. at 203. While courts have found failures to represent fairly where the basis for disparate representation was deemed "irrelevant," e.g., Berman v. National Maritime Union, 166 F. Supp. 327 (S.D.N.Y. 1958); Brotherhood of Locomotive Engineers, 116 F. Supp. 3 (D.D.C. 1953), what is deemed "relevant" has a very broad scope. See Ford Motor Co. v. Huffman, 345 U.S. 330 (1953).

${ }^{18}$ Compare Amalgamated Ass'n of St., Elec. Ry. \& Motor Coach Employees v. Lockridge, 403 U.S. 274, 301 (1971) ("[T] he very distinction . . . between honest, mistaken conduct, on the one hand, and deliberate and severely hostile and irrational treatment, on the other, needs strictly to be maintained."), with Vaca v. Sipes, 386 U.S. 171, 190 (1967) (mandate that the union refrain from engaging in conduct that is "arbitrary, discriminatory or in bad faith").

"See Amalgamated Ass'n of St., Elec. Ry. \& Motor Coach Employees v. Lockridge, 403 U.S. 274, 301 (1971). But see Clark, The Duty of Fair Representation: A Theoretical Structure, 51 TexAS L. REv. 1119 (1973). 
gaining contract. Those are no longer the issues. The issues now center on the individual's allegations and interests. Moreover, there are opportunities, albeit not unilateral, for the union to amend the contract if an individual grievance is settled in a manner which the union does not want. If the issues were still general, rather than specific, still a matter of unit concern, where could an individual ever find vindication of the legitimate interests that he or she has as a result of the collective bargaining contract and the expectations that the contract has created?

The almost universal fact that the union was opposed by a minority of the employees who now must look to that organization for representation in their individual grievance proceedings compels one to come face to face with a real novelty in our law, to which reference has already been made: An individual is forced to use a representative not of his or her own choosing to settle an individual grievance or complaint. Indeed, the representative may be antagonistic to the employee, either personally or ideologically. Nevertheless, the law tells us that these individuals must be represented by such unsympathetic institutions.

As protection, the Supreme Court has held that the duty of fair representation applies to grievance and arbitration proceedings. ${ }^{20}$ This might be of some protection if the duty were broadly and clearly defined, but the courts have yet to set forth such an exposition. Moreover, proof of a violation of the duty of fair representation does not make out a successful case against the employer under the collective contract: The individual must prevail on the contract issue as well. The individual probably has to prevail on the contract issue even if the union is the only defendant, because it is difficult to show how the employee has been injured by the union's failure to represent fairly unless there was a contract right at the bottom of the employee's claim.

While this appears to make sense, at least at first blush, it is neither reasonable nor fair that the employee can successfully sue the employer on the contract only when the union also violates its duty of fair representation. After all, if the employee's contract rights were violated, what relevance has the union's behavior to an action between the employee and employer? Nevertheless, in Vaca $v$. Sipes, ${ }^{21}$ the Court held that an individual

${ }^{20}$ Vaca v. Sipes, 386 U.S. 171 (1967).

${ }^{21}$ Id. 
has to prove a failure of fair representation before he or she can sue an employer on the collective bargaining contract. On one level, the Court's reasoning seemed to be that the union and the employer were the parties to the contract (whatever happened to the employees?) and that it therefore followed that the union had to be dissatisfied with the employer's actions and seek redress if any relief was to be had (unless the union acted illegally in its acquiescence, in which case the individual needed protection). On another level, the Court appeared to be saying that the union needed to participate in all grievance settlements because whatever was decided could affect all the other employees whom the union represented.

There is some truth to both levels of analysis, but neither is wholly persuasive. First, the fact that a union does not pursue a grievance does not prove that the union, one of the two parties recognized by the Court, agrees with the other party-the employer. The union may have chosen not to pursue the grievance for reasons which were legitimate, at least for fair representation purposes, but it might still agree with the employee's position on the merits of the grievance. Secondly, while many grievances have elements which may have some impact on other employees, this is obviously a more or less proposition, varying from case to case. Resolution of seniority disputes can affect large numbers of employees, while resolution of a discharge case where the only issue is whether an employee showed up late for work may involve no other employees' interests at all; as a practical matter. While drawing the line is made easier by opting for the idea that other employees' interests and the union's interests are always involved, that hardly comports with the legitimate interests of the grieving employees. Sometimes the grievant's interests far outweigh the union's or other employees' theoretical concern.

Finally, it should be noted that, in the past, the Supreme Court has ordered arbitration in one case although it was plain that one of the parties most likely to be affected would not, and could not, participate. In Carey v. Westinghouse Electric Corp., ${ }^{22}$ the Court ordered an arbitration between an employer and one union which had a jurisdictional dispute with another union not involved in the litigation or in the arbitration-to-be. What 
legal impact the required arbitral decision might have on the unrepresented union was not decided by the Court. If the Court can order such an arbitration where it is virtually certain that further litigation or arbitration would be necessary to resolve the matter because an interested union was absent, surely one can have doubts about the sanctity of requiring a union to participate voluntarily when an employee seeks justice from his or her employer. Combining with this the fact that there is often reason to be suspicious of union motivation for refusing to process grievances, especially since the grievant may have all sorts of unprovably bad relationships with union leaders and the leaders all sorts of unprovably hostile motives towards the individual, one must conclude that the Vaca solution does not make sense.

A more appropriate, albeit not perfect, solution under the existing statutes is the following:

1. If an employee is severed from employment, he or she is able to sue the employer on the contract without exhaustion of contractual remedies (so long as the employee does not seek reinstatement)..$^{23}$

2. If the employee has not been severed from employment, or he or she seeks reinstatement as a remedy, the employee has the right to take up the grievance, although not the right to force the union to pursue it. ${ }^{24}$ If the union chooses not to support the grievance formally, the employee is entitled to a written reason why the union will not pursue the matter; the reason

${ }^{23}$ This once was the law under the Railway Labor Act. Moore v. Illinois Central R.R., 312 U.S. 630 (1941). The Supreme Court first refused to extend Moore to Taft-Hartley cases, Republic Steel Corp. v. Maddox, 379 U.S. 650 (1965), and then overruled Moore entirely. Andrews v. Louisville \& N.R.R., 406 U.S. 320 (1972).

${ }^{24}$ See the proviso to $\$ 9(a), 29$ U.S.C. $\S 159(a)$ (1970), which states: "[A]ny individual employee or a group of employees shall have the right at any time to present grievances to their employer and to have such grievances adjusted, without the intervention of the bargaining representative as long as the adjustment is not inconsistent with the terms of a collective bargaining contract or agreement then in effect." Despite the more obvious meaning of this language, which creates an exception to the purity of exclusivity on behalf of the employee, the usual interpretation given these words is limited to permitting an employer, if it wants, to discuss a grievance directly with an employee. E.g., Black-Clawson Co. v. Machinists Lodge 355, 313 F.2d 179 (2d Cir. 1962). It makes more sense to give the individual employee the right to settle grievances. In this fashion, the employee is more apt to be satisfied and the employer is more likely to hear employees' problems. Since the proviso assures the union's presence at the grievance discussions, it is difficult to understand any harm that can befall exclusivity concepts by assuring an individual this limited right. See, e.g., Donnelly v. United Fruit Co., 40 N.J. 6I, 190 A.2d 825 (1963). I do not accept the Donnelly opinion, however, where it suggests 
should set out what efforts the union made to investigate the grievance as well as the reasons for its abandonment. The union must follow reasonable procedures to investigate, and the union is expected to have reasonable grounds for not pursuing the matter. If its motivation was improper (unreasonable or irrelevant), the stated reasons would in no way bind the employee. If the evidence does not support the union's position, or if its reasons for not pursuing the grievance are improper, the employee should be successful in a fair representation action. A fair representation action should be permissible without proof that the employee was correct on the contract claim; it should be enough that the employee lost a chance of winning the contract claim because of the union's mal- or misfeasance. ${ }^{25}$

3. The employer may be liable to the employee on the contract, even if the union does not pursue the grievance through arbitration and even if the employee is not separated from employment, if (a) the union is guilty of a failure to represent fairly, (b) the union does not agree with the employer's position but has failed to pursue the matter for reasons which do not violate the duty to represent fairly, or (c) although the union agrees with the employer, the union's reasons for not pursuing the grievance do not significantly or legitimately involve the interests of other employees covered by the contract. ${ }^{26}$

4. The employee should not be required to join the union and the employer as defendants in order to succeed against either.

an individual can even insist upon going to arbitration. This seems, to a considerable extent, a futile gesture for the employee. Moreover, the dilemma of identifying the "parties" to the arbitration may be more trouble than it is worth. Finally, such a doctrine might result in unfair financial burdens. However, as indicated in the text, the individual's rights in the courthouse should be greatly expanded.

25. The fact that paragraph "three" permits the employee to sue the employer on the contract if the union fails to represent fairly should not preclude the employee from suing in fair representation only, and having the damages measured in terms of a lost chance to prevail on the contract issue. In some situations, at least, that chance will not be equated with the merits of the contractual dispute. This will be true especially where the designated interpreter of the contract is an arbitrator, not the courts.

${ }^{26}$ It should be noted that the proposal made in the text does not wholly reject some of the institutional interests protected by Vaca. If the union's refusal to support the individual is based significantly on the legitimate interests of other employees, e.g., a seniority dispute, I am prepared to leave a real contract issue to the interpretation of the creating parties, the employer and the union. However, there are limits to the rational meaning of words and, beyond that point, the courts should not defer to the parties' contract interpretation when it comes at the expense of identifiable individuals. 
5. An employee should never be required to exhaust internal union procedures before suing either the employer on the contract or the union for failing to represent fairly in a grievance context. ${ }^{27}$

6 . If the union does choose to pursue a grievance to arbitration, an individual employee may employ his or her own representative for the proceeding. ${ }^{28}$

While these proposals would not completely protect legitimate interests of individuals, they would go a long way without abandonment of the exclusivity doctrine.

\section{B. Board Abstention in Individual Rights Cases}

A few years ago, the National Labor Relations Board reversed its then longstanding practice of virtually never deferring to the arbitral process. ${ }^{29}$ Much can be said for the NLRB's decision to abstain from deciding a case in which the arbitration process is available to resolve an issue revolving around the authority of the employer to impose "unilaterally" changed working conditions during the term of a collective bargaining contract. ${ }^{30}$ In such a case, there can be no "unilateral action" if the contract authorizes the employer conduct; any unfair labor practice finding would necessarily turn solely on the meaning

${ }^{27}$ A growing body of law is requiring employees in Vaca contexts to exhaust both contractual and internal union remedies, even in cases where the employer is the defendant. See Simpson \& Berwick, Exhaustion of Grievance Procedures and the Inditidual Employee, 51 Texas L. Rev. 1179 (1973).

${ }^{28}$ Note that the proposal does not authorize an individual to enforce arbitration where neither the union nor the employer seek it. This assumes, of course, that the contract does not authorize individual authority to initiate arbitration. The reason for this apparent omission is primarily a skepticism about an arbitrator's ability to retain an objective and fair stance when his or her "employers," the union and management, are opposed to the arbitration. Even the right of counsel contained in paragraph "six" may not be worth much. Either the union will support the individual, in which case the independent attorney is probably not needed (although his or her presence may assure more competent representation), or the union will not support the claim, in which case the arbitrator's neutrality will be somen hat suspect. (Of course, the arbitrator may not be aware of the union's indifference or animosity to the individual's claim, and the attorney's presence may prevent the union from being open about its true attitude. Moreover, the union's indifference may be reflected in poor advocacy, which the attorney may cure. Alternatively, the arbitrator may treat the presence of such an attorney and everything he or she does with considerable skepticism, given the fact the attorney does not speak for either the employer or the union.)

2" Collyer Insulated Wire, 192 N.L.R.B. 837 (197l).

${ }^{30}$ Se' Schatzki, NLRB Resolution of Contract Disputes Under Section 8(a)(5), 50 Texas L. Rev. 225 (1972). 
of the agreement. However, abstention is wrong in cases in which the issue centers on identifiable individuals and their interests in their employment relationship. ${ }^{31}$ Unfortunately, the Board has made no such distinction and has abstained whenever arbitration is available in these types of cases. ${ }^{32}$ In a typical 8(a)(3) discharge case, for example, the arbitrator deals with a "good cause" provision of a contract, while the Board deals with a federally legislated mandate which does not look' to the contract for its meaning. Unlike the unilateral change cases, there is reason to believe in cases involving individual interests that sometimes-perhaps often-the union's interests and those of the involved employees may be different, or even antagonistic. In the non-unfair labor practice case in which the individual seeks to protect his or her own interests by challenging employer behavior, the individual is limited to the meaning of the contract, to some sort of relief authorized by the contract, and to union representation. In unfair labor practice cases the employee can rely upon federal substantive law and remedies and can look to the General Counsel and the Board to protect his or her federal rights. Surely, the assurance of greater impartiality (greater, certainly than an arbitrator or bipartite board that is "controlled" by the union and the employer) is justification enough to have the Board exercise its authority in these cases. Recognizing fully the problems of drawing lines between "unilateral action" cases and "individual interest" cases, I believe it is well worth delineating. It is certainly preferable to the current

${ }^{31}$ See Atleson, Disciplinary Discharges, Arbitration and NLRB Deference, 20 BuFF. L. Rev. 355 (1970); Getman, Collyer Insulated Wire: A Case of Misplaced Modesty, 49 IND. L.J. 57 (1973); Schatzki, Earliest Returns from the NLRB's New Deferral Policy in Collyer Insulated Wire, Procendings of N.Y.U. Twentry-Fifth ANnUal Conference ON LABOR 97 (1973).

32 For an extreme example of deferral in a layoff case, see Electronic Reprod. Serv. Corp., 87 L.R.R.M. 1211 (1974). The union claimed, among other things, that two employees had been laid off in violation of the federal labor laws. The case went to arbitration and the arbitrator upheld the layoffs without making any reference at all to the claim of unlawfulness. Apparently the employer had urged the arbitrator to determine the statutory issue, but the union refrained from pursuing the issue or putting supporting evidence into the record. Regarding the unfair labor practice charge, the NLRB deferred to the arbitration award although there was no evidence the issue was ever litigated in that forum. The inference to be drawn from this case is that although the contract and statutory issues are different, the union's interests may not coincide with the individuals', and the statutory issue was in no way litigated or determined, the Board will deprive these individual employees of their statutory rights under the guise of deferring to and encouraging arbitration. One's mind would need to be very fertile, indeed, to conjure up a more shocking sacrifice of individual rights on the altar of institutionalism. 
assumption that the collective bargaining process will always provide individuals with adequate and fair process.

Many of the problems created by the Board's abstention appear to be a product of the exclusivity doctrine, just as the Vaca problems are. That is, the Board is prepared to defer to the collective bargaining process in the hope of encouraging that institution, a worthy goal indeed. ${ }^{33}$ However, the unspoken premise is that the exclusive representative will do its best for all individuals, regardless of the nature of the dispute or the identity of the involved workers. This belies common sense. It is true that the Board has set up some guidelines which are meant to protect against abuses by unfriendly exclusive bargaining representatives; but the Spielberg doctrine's criteria are more defective than the limited protection given the individual by the duty of fair representation. ${ }^{34}$ No one has any difficulty making an arbitration decision appear to be fair and consistent with the substantive provisions of the Act, especially when one of the parties of real interest-the individual-has no control over the nature of the proceedings, the selection of the "neutral," the presentation of evidence, or his or her "representative." Would the assumption of regularity be fairer and comport more often with reality if we knew that the individual employee, in fact, wanted the particular union to represent him or her?

\section{Preemption Problems}

The idea of using the federal labor laws to preempt state and federal courts from hearing cases arising in labor relations contexts is well established and well discussed, although not altogether clear. Whatever the scope of preemption in the labor law area, it is accepted dogma that fair representation cases are exceptions to the preemption doctrine.$^{35}$ However, in the Supreme Court's last effort in the preemption field in which individual employee rights were in issue, the Court's majority

${ }^{33}$ See Electronic Reprod. Serv. Corp., 87 L.R.R.M. 1211 (1974), where almost the entire analysis of the Board opinion centers on encouragement of arbitration, part of the collective bargaining process, no matter what the cost to individual employees.

${ }^{34}$ Spielberg Mfg. Co., 112 N.L.R.B. 1080 (1955) (the Board will defer to an arbitration award in a discharge case if the hearing was fair and the award was consistent with the policies of the Act). Doesn't Electronic Reproduction undo whatever rationale there was for Spielberg?

${ }^{35}$ See, e.g., Amalgamated Ass'n of St., Elec. Ry. \& Motor Coach Employees v. Lockridge, 403 U.S. 274, 299 (1971). 
made it clear that the fair representation exception to preemption should be construed narrowly. ${ }^{36}$ Indeed, the Court went to considerable effort to vindicate the preemption precedents, especially the famous Garmon decision, ${ }^{37}$ even as applied to cases involving individuals' interests, whether the plaintiff was suing in fair representation, on the collective bargaining contract, or on the union constitutional contract. In Amalgamated Association of Street, Electric Railway and Motor Coach Employees $v$. Lockridge, ${ }^{38}$ an employee was discharged from his job at the request of the union. The collective bargaining contract provided that employees who did not remain members of the union could be discharged for that reason. The union's constitution provided that a member was in bad standing if he was more than one month in arrears of dues payments and that he was to be suspended from membership if he was two months in arrears. The union successfully requested Lockridge's discharge after he was only a few days more than a month in arrears. The apparent, or at least possible, motive for the quick action against a longtime employee and longtime member was that Lockridge had recently withdrawn his checkoff authorization. Eventually, the Supreme Court held that the state court did not have jurisdiction to hear Lockridge's complaint, since the National Labor Relations Board's jurisdiction preempted all else. In effect, the Court held that the general needs of the Act, more or less left undescribed in the opinion, must be vindicated at the expense of protection of individual workers. Is not the federal policy to which the Court obliquely referred the need to protect the union's countervailing power and, therefore, the institution of exclusivity, which is fostered by federal law and better appreciated and protected by the federal agency? ${ }^{39}$ In the process

${ }^{36}$ Id. at 301 .

${ }^{37}$ San Diego Bldg. Trades Council v. Garmon, 359 U.S. 236 (1959). The Garmon case articulated the standard for preemption that the Lockridge Court appears to have applied: No conduct either protected or prohibited by the Taft-Hartley Act, or arguably protected or prohibited by that law, can be regulated by state or federal courts. However, one should note that Garmon did not involve an individual worker attempting to vindicate his or her rights; rather, it was a case in which an employer attempted to enjoin a union's picket line.

38 403 U.S. 274 (1971).

${ }^{39}$ In a footnote, the majority suggested of Justice llhite's dissenting opinion, "At bottom, what his opposition seems to imply is that giving the National Labor Relations Board jurisdiction to enforce federal law regulating the use of union security clauses was largely, if not wholly, without rational purpose." Id. at 288 n.5. The majority rejected Justice White's attack on this manifestation of exclusivity, thus preserving the doctrine in its pristine form. 
of upholding exclusivity, the Court gave no weight whatsoever to the substantive and procedural interests of the individual worker, interests which Justices Douglas and White articulated in their dissents. For example, can it be argued rationally that if the General Counsel did not issue a complaint on a Lockridge charge primarily because of budgetary priorities, Congress desired to foreclose a Lockridge from any remedy? How could the Court decide the case without at least attempting to resolve or balance the competing substantive interests? Is the union's countervailing power threatened if Lockridge can sue in the state courts? ${ }^{40}$ The decision appears to be another example of adopting the logical and extreme consequences of exclusivity without taking into account the conflicting needs which create the disputes in the first place.

There are several alternatives to the result reached in Lockridge. Some need legislative support. All have some weaknesses. But perhaps most importantly, they give needed added protection to the individual caught in Mr. Lockridge's dilemma, to wit, being kicked out of the union for alleged tardy dues and thereby losing his job as well. The alternatives, without much effort to describe the advantages and disadvantages of each, are the following:

1. There should be no preemption when an individual employee is the plaintiff (one can be skeptical about what significant harm to the legislative purpose would be done by such a standard);

2. Cases which are at the "core" of the Act should be preempted, but no others (it is difficult to see Lockridge at the core of the Act, especially if one accepts the Court's insensitive view of the individual's interests); ${ }^{41}$

3. The concept of fair representation should be expanded, keeping in mind that it continues to be an exception to the preemption doctrine and that it is a federal question which can always be heard in the federal courts, which should be more

40 The real basis for the Court's decision may be nothing more than distrust of state courts and the latter's possible bias against labor unions. The Court did express its concern that state courts may impose all sorts of outrageous remedies which could upset the balance attempted by Congress. Id. at 288-89 n.5. But wouldn't the possibility of removal, which surely would be available in fair representation cases, be adequate protection from that abuse? See Bryson, A Matter of Wooden Logic: Labor Law Preemption and Indizidual Rights, 51 TeXas L. Rev. 1037 (1973).

${ }^{41}$ See Cox, Labor Law Preemption Revisited, 85 Harv. L. Rev. 1337 (1972). 
protective of, sympathetic to, and understanding of federal legislation than state courts might be; ${ }^{42}$

4. The role of the courts in reviewing the General Counsel's dismissal of charges filed in his office should be expanded (this, at least, would give the individual charging party some review of what is now a wholly unreviewable process and, probably, a process which often dismisses cases for administrative convenience rather than on the merits); ${ }^{43}$

5. The Board should be authorized to issue declaratory judgments regarding rights under the Act (somewhat like Internal Revenue Regulations) (while there are some difficult procedural problems with this solution, the proposal might make clear, sometimes, that the Board does not have jurisdiction in a particular case, thereby freeing the individual to go to the courts);

6 . The charging party, at least if he or she is an individual worker, should be allowed to litigate before the Board, whether or not the General Counsel issues a complaint;

7. The individual charging party should be allowed to litigate before the court if the General Counsel does not issue a complaint. ${ }^{44}$

Any of these would have been better than the treatment Lockridge actually received.

\section{Union Disciplinary Action Against its "Members"}

May a union fine a member for crossing a picket line or violating some other work-related internal union rule? May the union sue to enforce the fine? Or do such actions constitute violations of section $8(\mathrm{~b})(1)(\mathrm{A})$ of the Act, which forbids unions from restraining or coercing employees in the exercise of rights granted by the Act? Should it matter whether there is a union shop in effect, which compels some sort of "allegiance" to the union? The Supreme Court has held, by and large, that the

42 See Bryson, supra note 40; Clark, supra note 19.

${ }^{+3}$ But see Lesnick, Preemption Reconsidered: The Apparent Reaffirmation of Garmon, 72 Colum. L. Rev. 469, 484 (1972). Professor Lesnick appears to reject the idea of judicial review of General Counsel dismissals, but urges reform of General Counsel procedures to protect individuals. While his proposal is desirable, I doubt that it would accomplish very much in terms of protecting individual workers.

${ }^{44}$ It is also possible that there should be no preemption if the conduct under review is only arguably protected or arguably prohibited by the Act. W'hile such a revision of the Garmon doctrine vould undoubtedly protect many more individuals, the change would also have considerable impact on preemption generally and in ways that, at least for the present, I am not prepared to endorse. 
union can do all of this, even in situations in which there is a union shop provision in the collective contract which requires "union membership" in order for the employees to retain their jobs. ${ }^{45}$ It is true that sophisticated lawyers know that employees do not have to become real members in order to retain their jobs in shops which have union security clauses: all the employees need do is tender dues and fees uniformly required of all union members. However, the statute does not read quite so clearly, and it would not be surprising for employees, most of whom have never read the law, to believe that they must join the union in order to keep their jobs. Moreover, many employees are going to feel intimidated into joining the union in order to avoid having the union prejudiced against them when it comes to questions of their work status. Finally, employees are coerced (induced?) into joining their exclusive representative because, once having the union imposed upon them, they might as well join and have some voice in selecting their spokesmen and in determining what policies the union should follow. The fact that these employees receive some "quid pro quo" for joining hardly changes the fact that they might prefer another (or no) union, or that they may be unpopular within the union because they either opposed the union or oppose the current internal union policies. They have joined the union either because they feel the law requires it, or because the practical consequences of being represented by the union (not of their choice) require it (whether or not there is a union security clause).

45 Scofield v. NLRB, 394 U.S. 423 (1969) (in the presence of an agency shop clause, a union does not violate the Act by fining and suspending members for producing more work than permitted by a union-imposed ceiling); NLRB v. Allis-Chalmers Mfg. Co., 388 U.S. 175 (1967) (in the presence of a union shop clause, a union does not violate the Act by fining and suing members for crossing a lawful picket line). For purposes of the Act; it is irrelevant how exorbitant the fines may be. NLRB v. Boeing Co., 412 U.S. 67 (1973).

There appear to be some statutory limits on a union's ability to fine its members. NLRB v. Granite State Joint Board, 409 U.S. 213 (1972) (a union violates the Act when it fines members for abandoning a strike, although those same employees voted to strike and to fine members who did not strike, because the fined members had resigned from the union prior to returning to work. Would a provision in the union's by-laws or constitution which forbade members from resigning during a strike be a good defense for the union? One cannot know, although the Court's opinion seemed to rely heavily on the absence of such a provision.); NLRB v. Industrial Union of Marine \& Shipbuilding Workers, 391 U.S. 418 (1968) (unfair labor practice for a union to expel a member for filing an unfair labor practice charge against the union alleging that the union had earlier caused an employer to discriminate unlawfully against the employee; this case can be read as merely protecting the process of the Act, rather than the individual employee). 
Despite the obvious reservations anyone should have about the voluntariness of the employees' membership in the union, the Court has upheld union discipline of these employees for crossing picket lines or violating other work rules which had no substantive basis other than that the rules reflected what the union thought was desirable. If the membership was not voluntary but, rather, a product of exclusive representation, should not the Court forbid the union's enforcing its rules in a manner which affects the employees' job opportunities? To put it differently, if employees do not want to strike, does not section 7 indicate that such a decision is protected by the Act? If so, how can anything less than an individual's voluntary abandonment of his or her section 7 rights be considered an adequate waiver of those rights by the individual?

If the Act clearly stated that employees did not have to join any union, and that they would never be represented by any union other than one of their individual choice, then one would have more sympathy with the Court's conclusion that a union ought to be able to fine its members for not abiding by union rules. That is not the law, however. The Court's decisions constitute another example of vindicating the institution of exclusive representation at the expense of individual employee interests.

\section{E. Wildcat Strikes}

In some situations, employees who are dissatisfied with their working conditions will strike even though they are represented by a union which has not authorized the strike action. The union's failure to support the individuals' action may be due to disapproval, indifference, inability, inactivity, ignorance, or timidity. The individuals' action may be inconsistent with the union's substantive positions, plans, or tactics. Unless the union quickly makes plain its support of the action, thereby ratifying the employees' conduct, the employer will likely find itself dealing with two groups (the strikers and the union) rather than the one designated as the exclusive bargaining representative.

It is not surprising, then, that the Board and the courts have looked upon wildcatting as undesirable. Having reached that conclusion, these institutions followed with the principle that such activities are not protected by section 7 of the Act. ${ }^{46}$ That

${ }^{46}$ See, e.g., Emporium Capwell Co. v. Western Addition Commun. Org., 95 S. Ct. 
is fully consistent with those institutions' proclivity to deny protection of the Act whenever there are any legitimate institutional considerations competing with the protection suggested by section 7. In wildcatting cases, the argument for giving the employer the opportunity to punish employees is twofold: First, the union almost surely is not supporting the individuals and, therefore, it cannot be said that the employees are the innocent pawns of the union; second, the employees' conduct, almost by definition, upsets the exclusive nature of the collective bargaining agent's role in its dealing with the employer and the concomitant interest of the employer in relying on that exclusive agent. Of course, the second reason is the key, for without it the first reason would not justify any remedies for the employer. The first reason assumes that there is something "wrong" with the employees' conduct, and that ingredient is supplied by the activity's interference with the exclusive representative's role and the employer's interest in relying on exclusivity.

The difficulty with all of this, however, is that employees may not have their legitimate interests vindicated by traditional collective bargaining. Their behavior reflects sufficiently deepseated unhappiness with certain working conditions (and, sometimes, with their union) that they are prepared to engage in this disruption without any institutional support and perhaps with the union's opposition. ${ }^{47}$ If they do not engage in this form of disruption, the employees may well engage in other sabotage of the employer's business, such as slowdowns, destruction, and sloppiness. It is not clear that wildcat strikes produce greater inefficiencies than those employee responses. Thus, reliance on the exclusive representative concept may often result in greater inefficiency as well as in dissatisfaction with working conditions which, from the employees' point of view, reflect employer interests but not those of the employees. ${ }^{48}$

While wildcatting highlights the fractionalized nature of the collective bargaining unit, it does not create it; these units already suffer strong and bitter fractionalization, or there would

977 (1975); Lee A. Consaul Co. v. NLRB, 469 F.2d 84 (9th Cir. 1972); Plasti-Line, Inc. v. NLRB, 278 F.2d 482 (6th Cir. 1960); NLRB v. Draper Corp., 145 F.2d 199 (4th Cir. 1944); Atleson, Work Group Behatior and Wildcat Strikes: The Causes and Functions of Industrial Citil Disobedience, 34 OнIо Sr. L.J. 751, 755 (1973).

is The union may approve of the activity but, for various reasons, feel that it cannot say so.

${ }^{48}$ See Atleson, supra note 46. 
not be such open defiance of authority. To avoid such consequences, and to hold the unit together, collective bargaining often reflects the split personality of the bargaining unit, and certain subgroups may be given unusual powers within the unit to determine collective bargaining postures for the union. ${ }^{49}$ Is it clear that the wildcatting greatly exacerbates the situation when subgroups do not have this power? Moreover, may it not be the case that wildcatting helps the weaker elements of the employees who do not have a sufficient voice within the union to have their views aired, pursued, and struggled for by the union? May not wildcatting give some cathartic release to these frustrated employees, who may work more efficiently and less resentfully after the strike? Finally, is it not true that only the strong employer can take advantage of the law which permits it to discharge wildcatters? Weak employers have no choice but to put the employees back to work. To the extent, then, that the law has developed to protect employers' interests, it makes very little sense, because it helps only those employers who need it least. To the extent that the nonprotection of wildcatting is to discourage employees from engaging in such activities, the inclination of employees to find other ways to subvert the employer's efficiency seems sufficiently likely to make effective deterrence an unlikely objective. Finally, if the law has developed to protect internal cohesiveness of the collective bargaining unit, the fact that fractionalization of the bargaining unit is not new or unique and is a problem with which unions must wrestle all the time, especially given the union's role as the representative of all the employees in a particular unit, dictates that wildcatting is not such a serious problem.

4: Article $19, \S 3$ of the constitution of the International Union, United Automobile. Aerospace and Agricultural Implement Workers of America (1974), provides in its second paragraph:

Upon application to and approval of the International Executive Board, a ratification procedure may be adopted wherein apprenticeable skilled trades and related workers, engineers, and technicians would vote separately on contractual matters common to all and, in the same vote, on those matters which relate exclusively to their group.

While this provision has not been interpreted to give skilled workers a veto power over ratification of a proposed contract, the constitution assures that skilled workers do have separate recognizable interests which may, under some circumstances, receive formal recognition by the union and may affect the union's bargaining stance. For a current interpretation of article $19, \S 3$, see Poszich v. International Union, UAW No. 316 (UAW Public Review Board 1974). 
To the extent that the competing interests in a wildcat context present a difficult problem under current law, most of the difficulties are caused by the exclusivity doctrine.

\section{F. Union Security Clauses}

In the debates over the Wagner Act, unions fought very strenuously for the exclusivity concept. ${ }^{50}$ Having prevailed, the unions argued during the Taft-Hartley debates, and often afterwards, that the "right-to-work" attacks on union security clauses were misplaced because the unions had the burden of representing all the employees in a unit, and there should be no "free riders." 1 How curious that the unions should fight so vigorously for the "burden" of representing people who do not want the union to represent them, but then should argue for fair payment by these dissidents. Of course, the two positions can be reconciled by pointing out, if it is true, that the labor organization can more effectively represent employees (even those who oppose the union) if the majority principle is invoked. That responsibility (or "right," if you like) having been established, there is no reason to excuse beneficiaries of the union's work because these individuals did not want the union in the first place-they still are beneficiaries.

While this reconciliation of the union posture may satisfy, it does so only if one is convinced that, because of exclusivity, the unions accomplish a sufficient amount for the employees to justify the clear cost of the loss of freedom for the individual dissenters. In a sense, that is the question I raise by this Article: Do unions accomplish enough because of the exclusivity concept to justify its considerable interference with the individual employees' freedom? ${ }^{52}$

\section{G. Conclusion}

Having attempted over the years to understand why the law has developed in a fashion which deprived individuals of so much freedom and protection in the collective bargaining rela-

\footnotetext{
so Se lleyand, Majority Rule in Collective Bargaining, 45 Colum. L. Rev. 556, $565-67$ (1945).

"See, e.g., 2 Legislative History of THE LMRDA 1040-41 (1959) (remarks of Sen. Moss). See also 113 Conc. Rec. 140 (1967) (remarks of Rep. Rhodes).

.2 A sibling of the concept of the union security clause is the exclusive hiring hall, which becomes the sole (or, the first and primary) source of labor for employers in certain fields, especially the construction and longshore industries. For
} 
tionship, I have come to the view that the Board and the courts have misunderstood the appropriate dimensions of the exclusivity doctrine. One way to undo the mischief, obviously, would be wholesale reversals and modifications of the case law. That is implicit in Part I of this Article. That remedy, however, seems very unlikely; others have already made that pitch, but to no avail. Alternatively, why shouldn't exclusive representation be abolished through legislative action? I have found it difficult to answer this question. Since I am neither a philosopher nor an economist, the suggestion is being made here with some trepidation. However, the following proposal is made with the hope that it will stimulate more thought about the virtues and vices of exclusivity. ${ }^{53}$

\section{A Proposed Model for Collective Bargaining Without Exclusive Representation}

The keystone of a model of collective bargaining which did not allow majority rule to determine the bargaining agent would be the principle that every employee could select his or her own representative, if any. No one would be represented by a labor organization unless it was actually selected by that individual. Second, the employer would be obligated to engage in good faith collective bargaining with each of the collective bargaining agents authorized by that employer's employees. ${ }^{54}$ Third, the unions could engage in coalition or cartel bargaining, and the employer would be required to bargain on that basis.

a comprehensive examination of the pluses and minuses of such arrangements, see C. Summers \& H. W'ellington, Cases and Materials on Labor Law 911-69 (1968). After reading the account, can anyone conclude other than that the interests of individual workers have been sacrificed for the interests of employers, of unions, and, only possibly, of some employees?

${ }^{53}$ The concept of exclusivity is quite unique to the American experience. Why this is so is speculatively explored in Bok, Reflections on the Distinctive Character of American Labor Lau's, 84 HaRv. L. Rev. 1394, 1425-30 (1970), and Summers, American and European Labor Lat?: The Use and Usefulness of Foreign Experience, 16 Burf. L. REv. 210 (1966).

if The proposal does not suggest that an employer can choose to ignore the employees' designated representatives. The general concepts of unlawful attempts to deal directly with individual employees would not be significantly changed. See NLRB v. Katz, 369 U.S. 736 (1962); NLRB r. Crompton-Highland Mills, Inc., 337 U.S. 217 (1949); Order of R.R. Telegraphers v. Railway Express Agency, Inc., 321 U.S. 342 (1944); J.I. Case Co. v. NLRB, 321 U.S. 334 (1944). See generally Schatzki. The Employer's Unilateral Act-A Por Se Violation-Sometimes, 44 Texas L. Rev. 470 (1966). 
The proposal does not include any suggestion that employers would be freed of the sanctions of sections $8(a)(1)$ and (3) of the Act. Indeed, those sections, which have been the bulwark of the Act-at least when interpreted correctly-would be of increased importance to protect the employees' selection of the unions they desire.

In all likelihood, it might be necessary to limit how often employees could switch their allegiances from one union to another. It would also be necessary to devise a mechanism to inform the employer which employees belong to what unions. Those, I believe, are relatively unimportant problems.

A union would be free to refuse altogether to represent any employees of a single employer, but once the union agreed to represent one or more employees of an employer, it would not be allowed to refuse membership to any employee of that employer, nor to refuse to represent any employee of that employer. ${ }^{55}$ Moreover, there would be nothing illegal about a union requiring any employee it represents to join that union. The sanction for not joining the union which represents someone, however, would be merely to exclude the individual from the right to the contractual benefits of the collective bargaining process in which that union engages.

Very briefly, this is the model I propose be considered for nonexclusive representation of employees represented under the National Labor Relations Act. It is not meant to be complete, although a sympathetic reader could undoubtedly fill in the gaps.

\section{A. Benefits to be Derived from the Proposal}

While much of what I have to say in this section is all too obvious in light of what has already been said about the present state of the law, I trust the reader will bear with me. Also, I hasten to add at the outset that much of what I have to say about the potential gains and drawbacks of my proposal is, at best, speculation based on little or no empirical evidence. With that caveat (or admission), the following describes briefly what I believe may be gained by eliminating the exclusivity doctrine.

55 Perhaps a union could refuse to extend its representation beyond certain geographical limits, even though the employer had employees outside a particular geographical area. 
First, I contemplate a system in which the relationships are much more voluntary than they are at the present time. An employee will be neither represented by, nor coerced into joining, any union other than one that that employee wants. The consequences of this form of voluntarism may be many.

Employees who have the free choice to select and join a union are more apt, I think, to participate in the inner workings of their union. It is my judgment that a better form of union democracy is attainable under my formulation, at least if one understands greater participation to be "better." Wholly apart from anyone's vision of whether that is a good goal, the consequences of greater employee participation in union activities should increase union sensitivity to the individual employee's problems, since he or she will be more likely to partake, thereby increasing both the union's knowledge of employee interests and the political force of those employees within the union. The speculation that there will be increased participation is buttressed both by the likelihood that unions will be more sympathetic to special needs and interests of their respective memberships because they were selected, to some extent, for just that special sensitivity or interest, and because the unions may compete with one another for the allegiances of the employees.

While it is difficult to speculate with any sense of assurance what the nature of the local unions would be, it is possible that some locals would be smaller and likely that most would be more homogeneous, at least in terms of employee interests. In either event, it is likely that an individual would feel more at home and more encouraged to participate in the inner workings of the union. He or she would have more control of his or her destiny.

Employees would have control over the question whether they would be represented by one of possibly several unions. What those unions stand for, what interests they look out for, what zeal they demonstrate when protecting employees, all may have some impact on the employees' choice. The employees will be able to choose the unions which emphasize interests appealing to them. If an employee is interested in a union which advocates long vacations, he or she can select accordingly. If the employee wants a union that is zealous in pursuing grievances rather than wage increases, the selection can be made on that basis. If the employee wants to belong to and be represented by a union that is interested in skilled workers, that option would 
be available. And if the employee wants to select on the basis that the business agent is good looking, or that the politics of the union president are appealing, he or she can do that, too. But, in the end, the employee may well select a union which best represents-at least as the employee sees it - those individual interests about which he or she cares most.

The mere fact that employees do not have imposed upon them a union not of their own choosing may well cause them to be happier, more serene people. Happiness in employment is a significant goal in and of itself. Moreover, this mental state should result in more productive, less disruptive employees.

While the possible impact on the individual would be very significant, the speculated change in union conduct would be at least as important over a substantial period of time. Most obviously, unions would be forced to compete with each other in a manner that has not been present, by and large, under the present monopolistic doctrine of law. If unions wanted large memberships and a stronger opportunity to have their will accomplished, they would have to do better than win the hearts of a bare majority of the employees. If a union wanted to represent all, it would have to persuade all employees of its desirability. Faced with competition, which might become ever present, unions would attempt to be more aggressive in representing employees than has been their wont.

Just as employees will want to belong to and participate more in freely chosen unions that support their own interests, unions will respond more affirmatively to members who joined willingly, who have interests in common with the union, and who participate more fully in the union. In such a situation, the union almost surely will be more responsive than is the case today.

In the collective bargaining process, the presence of several unions would assure that more points of view get to the employer. Under the present state of collective bargaining, most of the compromising of competing employee interests is worked out within the union-sometimes for what we deem good and proper reasons, sometimes for reasons less likely to survive careful scrutiny. If the unions could no longer rely on exclusivity, each union which represented a segment of the employees of any employer would, after a period of time, present most forcefully the interests of all the employees it represented. Rather than being swapped out before the employer hears them, the interests would be aired, would have a professional advocate describing 
their worth, and would be called to the attention of the employer. While nothing is guaranteed, I suspect, first, that the interests are more likely to be vindicated, and second, that any frustration on the part of the employees will be lessened by the fact that they had a fuller hearing of their complaints than under the present system. (At least the boss heard the pitch.)

Consistent with the proposal, also, is the idea that the union is going to work harder and with more insight to win individual grievances. This is true for several reasons: the union and the individual employees are more closely identified in terms of their mutual interests and concerns; the individuals are more likely to be involved in union activities and therefore are going to constitute a more real internal-union political force; and the union will want to put on a good face, not only for those employees who have already selected it as their collective bargaining agent, but also to impress other employees that this union is the union to which they should belong.

I have one further observation about how the union is apt to act. In general, my impression is that under the present system (which includes exclusivity), unions are more responsive and more likely to be sympathetic and understanding if the individual who has a complaint or grievance is already a union member, preferably a "good" union member. While my proposal does not guarantee that all employees will be good union members, it does assure that unions will know that all the employees the union represents are willing members; I think that, by itself, will improve representation. To the extent that the individuals are more actively involved in the union, representation will be further improved.

While one cannot foresee the full scenario that would follow a change in national labor laws consistent with the proposal, one could guess that over a period of time employees would be likely to see more unions in action. If this were to come about, it would give the employees a more knowledgeable choice of which union, if any, they wanted representing them. I suspect that for many employees, it would be the first comparative shopping they have ever had an opportunity to engage in.

In Part I of the Article, I explored some areas of law which turn, in great part, on the exclusivity requirements of the present statute. Most of the legal problems discussed there would either no longer exist or would be greatly alleviated by abolition of the exclusivity doctrine. 
For example, the most severe problem raised by unions fining members for crossing picket lines is that the "members" may belong to the union only because they believed they had to do so, or believed that since they had to pay the union what members paid, they might as well get the benefits of membership. If exclusivity were abolished, it would still be true that employees might feel that they ought to join a union because the benefits from joining justified doing so. From that, one might argue that employees were still being coerced into either taking the bitter ("waiver" of the right to cross the the picket line) with the sweet (benefits of union membership and representation) or eschewing both; but the argument that employees are compelled to join unions is greatly reduced when they have a choice and understand that they have that choice. I think that is a distinct advantage over the present situation, in which the employee has, as a practical matter, no choice at all.

As I have already indicated, the problems reflected in the Vaca-type cases would also be greatly alleviated because, with unions made up only of willing and participating members, the unions might make a greater effort than they are presently inclined to, at least in some cases. Perhaps more importantly, we no longer would have employees being represented in their individual claims by a union often not of their choosing and, possibly, antagonistic to them or their claims.

Similarly, the proposal would remove much, if not all, of the doctrinal underpinnings of the fair representation requirements. While I think, for the reasons I have stated, much of the need for the concept would disappear with removal of the exclusivity doctrine, I also think for reasons explained earlier-that is, that unions ought to be held liable for their wrongful behavior, even in relation to employees who joined the union willinglysome remnants ought to be kept. This is especially true because I have suggested that once the union is willing to represent some of the employees of the employer, it must agree to represent all employees who want to join it. Whether the doctrine of fair representation would continue to find its bottom in the constitution or in contract/agency law is not terribly important.

Presumably, if employees select the union they feel will best represent the interests they value most, and if the employees feel that the union is, in fact, representing their interests better, there will be less wildcatting. The problems which both cause and are caused by wildcatting should be severely reduced; 
happier employees are less likely to upset everyone with their independent, disruptive behavior.

While the purpose of my proposal is to give individuals some freedom in the selection of their representative and thereby to avoid some of the unfortunate consequences of forced representation, another benefit would be to eliminate the need for the government to involve itself in notions of the appropriate unit and elections. Apart from the saving to be realized in time, effort, and money by relieving the Board of the necessity of studying units and conducting elections (a job which, in many aspects, defies rational demarcations), the employee will be assured of representation by his or her chosen collective bargaining agent regardless of the identity of the employer. For example, in these days in which mergers, sales of businesses, and the like are more frequent than ever, the complexities of the successor problem are rapidly becoming an impediment which will preclude any rational predictive or coherent patterns. Without the need for unit determinations, and with no elections to determine majority preferences, an employee can assume that the union of his or her choice will follow whatever change occurs in the employer's identity, unless the employee properly indicates otherwise. The very difficult problems currently faced by the Board and courts would be either eliminated or vastly alleviated. Consistent with the thesis of this proposal, the representative would follow the employee's individual choice and not the majority's; nor would the representative's role be determined by either the employer's identity or its structure. In a sense, the employees, rather than the Board, would determine the commonality of their interests. ${ }^{56}$

Skepticism about how rationally employees select unions in any event is appropriate; but to the extent they are in a position to make comparative judgments about the unions performing in their shops, they will better be able to select the union which is most likely to perform as each individual would want. And, of course, conversely, given this ability on the part of the employees to witness and assess, at least to some extent, the per-

${ }^{56}$ The suggestion that a union could limit its jurisdiction on the basis of geography, see note $\mathbf{5 5}$ supra, has within it some aspects analagous to the current "appropriate unit" law: However, even if the proposal were to allow a union to limit its representation to a certain geographical area (or, possibly, to a single plant of an employer), the problems of appropriate unit, as they exist today, would still be greatly lessened. 
formance of the unions, it is not unreasonable to assume that the unions will make greater efforts to satisfy the needs of the employee. Finally, the freedom of the employee to change unions if he or she is dissatisfied is increased by the proposal; the individual does not have to persuade or wait for a majority switch.

\section{B. Possible Drawbacks of the Proposal}

Having already conceded that my proposal is not being made with any assurance that it is better than other possible remedies for what I see as a developing body of law which ignores the interests of the individual workers to an unjustifiable extent, I shall now attempt to set out what I feel are the major potential difficulties with the proposal and why I am not persuaded that they justify jettisoning further consideration of the idea of nonexclusive representation.

\section{Solidarity Forever-Is It a Myth?}

At the time of the passage of the National Labor Relations Act, union advocates and economists argued strenuously to Congress that the exclusivity doctrine was a "must" if the Wagner Act was to work. ${ }^{57}$ Their theory, in short, was that the employees had to present a united front to the employer or they would compete with each other and undo each other's efforts to improve their lot. It is difficult to gainsay the idea that if the employees do not work together, but undercut each other's efforts, their chances of improving their conditions are not as great as if they worked in complete unity. However, why has it ever been assumed that all the employees would hang together merely because the law imposed an unwanted union on what was often a substantial minority? If that was not the assumption, and it seems to me that it is not a very realistic one, how was a union charged with representing all the employees to be more powerful, vis-à-vis the employer, in collective bargaining? Nevertheless, the two extreme scenarios contemplated by the supporters of the exclusivity doctrine must have been the following.

First, under the law as it has developed, all the employees are represented by one union. Collective bargaining occurs. The employer, faced with an employee complement which is unanimous in its support of any action of the union, will reach agree-

s Se' lleyand, supra note 50. 
ment with the union, or all the employees will go out on strike. Thus, solidarity in the workers, presumably caused by or tied in some way to the statutory mandate of majority rule and exclusive representation, works its effects upon the employer.

Second, without exclusive representation or an election, each employee designates the union of his or her choice or designates no union at all. Each union or individual then negotiates with the employer (or, a representative committee of all the involved unions negotiates). Of course, each union does not have the allegiance of any employees other than those it represents. The economic pressure which it can bring to bear is limited to the impact those employees can create by their strike or threat of striking. Since all the employees will not strike, the impact of the strike will be less, and the employee gains will be less. Put differently, if some of the employees are willing to work for, say, $\$ 2.50$ per hour and have union $X$ representing them, how can employees who perform the same kind of work get $\$ 3.00$ per hour by negotiating through union $Y$ ? Don't the ones working for $\$ 2.50$ undercut the effectiveness of any strike by their more ambitious colleagues?

Based on these two scenarios, it is argued that only exclusive bargaining can give employees hope of improving their status. I confess that I am not sure that there is not some truth to the scenarios and that the doctrine of exclusivity does not protect employees just as its most avid advocates claim. But I remain skeptical.

In cataloguing the types of individuals who will or will not support the union which represents all of them through majority rule, one can group the employees into four categories. First, there are the supporters of the union. Second, there are those who prefer another union but who will accept and support, as a second choice, the union imposed by the majority. Third, there are those employees who are coerced, either illegally or through the atmosphere of the workplace and their own misunderstandings and imaginations, into supporting the union. Finally, there are those who will not support the union. Of course, these categories are oversimplifications. For example, while some employees support their unions blindly, many will give their support on a more discriminating basis. The generalizations are intended to serve only as a guide for appreciating what the exclusivity doctrine gains for all the employees. 
Little needs to be said about the employees who support the union. Presumably, exclusivity gains no strength for the union vis-à-vis those employees. They will support the union whether it is the exclusive representative or merely their own representative.

If given their choice, some employees would support several other unions rather than the one selected by a majority, but they would also support any union-or at least more than the single union which would be their most preferred-if they could not have their first choice. But no one knows how many employees are of this ilk. My own sense is that there are probably relatively fewer persons today (than in 1935) who support the labor movement carte blanche, than those who give their support to one or a few select unions only. In any event, to the extent there are persons who will support a union other than the one they want most, the exclusivity doctrine gives a single union more strength in bargaining than does my proposal, which would obviously fracture support. Of course, it is possible that pursuant to my proposal, these employees who would support any union (or at least more than one) would continue to support unions other than their own through economic weaponry, such as honoring other unions' picket lines. The extent to which exclusivity increases this support is problematic.

Employees who may not be sympathetic to the majority union may still join the union because they are afraid not to. The coercion may find its roots in actual union behavior or only in the employees' imaginations. It matters not for the purposes being considered whether the employees' fears are real or imagined. These employees are not willing supporters of the union and should not be characterized as a group of the union's supporters whose continued existence should be legitimized by the law. To the extent my proposal reduces this coerced support, we should not be concerned.

Finally, as for the group which disapproves of the majority union that is currently the exclusive representative, I think it unrealistic to assume they will significantly support a bargaining representative which they oppose. The makeup of the legal structure for collective bargaining should have little impact on an individual's decision to withhold his or her services, unless there is a misapprehension of the law. Employees go on strike because they approve of the union or its objectives, or because they are afraid not to do so. While the law cannot and should 
not interfere too much with private sanctions such as social ostracism, it is clear that the law already forbids certain forms of coercion of employees by unions; that should not be changed. To the extent that my proposal would reduce the need or desire of unions to coerce employees to refuse to cross picket lines -as I think would be the case because there would be less institutional pressures for the union and nonmember employees to reach a mutual understanding on the matter-I think it would be a good development. Insofar as employees currently support only unions of their own choice or disputes of their own approval, I think my proposal involves no loss in economic power. That is, some employees currently do not support their majority representative when they do not want to.

However, it may be said also that an employer today may not get his employees back to work by making an offer that is acceptable to only some of the employees rather than to the union. ${ }^{58} \mathrm{My}$ proposal makes it possible for the employer to bid, in a formal way, for those employees who will sell their services most cheaply. Once those employees have agreed to terms, there will be more pressure for the other employees to capitulate, with the end result being that employees will receive considerably less than they do under today's collective system. The premise of this objection is that, under the current law and practice, such an offer does not weaken the union. But, of course, an offer (made to the union) which is acceptable to some of the employees does weaken the union's determination to reject it, because to the extent the offer brings back some strikers, persuades employees not to strike, or puts pressure (through employees) on the union to settle, the employer is able to undermine employee solidarity.

This argument, then, is a variant of the myth of employee solidarity. But it does raise a new consideration. Pursuant to current collective bargaining, it is conceivable that there are some employees who support their union because its position is close enough to those employees' own preferred views, and given the many other employees who support the union, these uncertain employees support it too. Under my proposal, they will not have to-they may have their own representative which will more closely fit its demands to their needs. If my proposal

${ }^{\approx 8}$ See NLRB v. Crompton-Highland Mills, Inc., 337 U.S. 217 (1949). 
were in effect, it is possible that more employees will be bought off, legitimately, by the employer's bidding technique.

There are some competing considerations, however. First, it is just as conceivable that unions sometimes will compete with each other to get the highest wage-or best benefits-possible. The competition for employees' allegiances may produce exactly the opposite result from the one raised by the objection under consideration - the unions will act more competitively with employers than they do under the present law and will force employers to make greater concessions than are presently sought or achieved. To the extent that is true, the employees are the beneficiaries of more effective representation. Probably, both of these phenomena would occur, resulting in greater benefits for some employees, less for others. In toto, I am at a loss to know which will outweigh the other.

Even if it were indisputably true that unions were more effective in obtaining financial gain for their "wards" with the doctrine of exclusivity than they would be without it, it is not clear that the costs to society would be so impressive if the doctrine were abrogated. Several possible alternative consequences might follow its abandonment. First, there might be no noticeable or significant redistribution of wealth and comfort in our society. A second possibility is that while there would be no redistribution as between organized workers and the rest of society, there might be some among the organized workers themselves. A third speculation is that there would be a redistribution between organized and unorganized workers. Fourth, there is the possibility that capital would be the victim of the abolition of exclusivity. And finally, of course, there is the chance that capital would be the beneficiary.

While one cannot be very sure about these things, there is some evidence which suggests that capital would not be significantly affected by a change along the lines I suggest. It appears that improvement in real wages in our society as well as the industrial nations of western Europe is closely tied to the growth in a country's gross national product and very little related to the size and growth of the labor movement. ${ }^{59}$ If this is true, a change in the way the labor movement operates may

59 E. Brown \& M. Browne, A Century of Pay: The Course of Pay and Production in France, Germany, Sweden, The United Kingdom, and the United States of AMerica, 1860-1960, at 95-104, 291-316, 317-22 (1968); A CartTer \& F. Marshall, Labor Economics: Wages, Employment, and Trade Unionism 361-68 
not have much effect on how much workers take home. While evidence supports this conclusion, it must be pointed out that the nature of our society has changed considerably in the last one hundred years, the period in which these studies have been made; it is conceivable that workers in both the United States and Europe would have been worse off without a labor movement, because the "natural conditions" for protecting workers have become worse during this period of time. I have in mind, in particular, the fact that more and more blue collar jobs require less and less skill. This means more persons can compete for the jobs which become available, and that the cost of their labors would be lower, but for the labor organizations. While I do not have the capacity to assess the relative strength of this factor which might have decreased real wages even in the face of growing gross national products, it is still quite possible that all workers as a class would be no worse off economically without unions.

While the above data suggest that we should at least have some doubts whether labor unions succeed in cutting into the capital of management, it seems beyond dispute that unions do effect a change, sometimes radical in nature, in the distribution of wealth between the organized and the unorganized workers in society. While capital and labor, as separate classes, have maintained a relatively stable proportionate share of the gross national product, one cannot gainsay that carpenters, for example, have done much better through most of this century than groups such as teachers, who were not significantly organized until recently. I mean to make no case for or against either of these jobs. Each has its important place. But it is hard to justify why the carpenters' rewards have been so much more impressively increased during this century than those of the teachers. I think no one would doubt that $a$, if not the, major explanation of this disparate development is the role of organized labor. The disparity has nothing to do with the inherent worth of the contribution of each type of work; nor does it reflect the number of years of preparation needed for the job. It reflects only the concept of the market, with carpenters being harder to employ at cheap prices because they refuse to compete with one another.

(1967); L. Reynolds, Labor Economics and Labor Relations 201-19, 657-61 (5th ed. 1970). But see G. Bloom \& H. Northrup, The Economics of Labor ReLATIONS 392-95 (7th ed. 1973). 
Thus, the labor movement's impact has been to pay organized labor more. Did this mean that employers made less? Not at all. What it meant was that carpenters' products cost more, and school teachers, who did not get the raise of the organized workers, paid the increased cost of the goods. In the end, the employer was protected, as was the carpenter; but the teachers realized less real income. It is my judgment that the most certain impact unions have had in our society's distribution of wealth has been to give to the organized worker and to take away from the unorganized.

If this is an accurate assessment of the impact of the labor movement, I am not deeply troubled by an alleged loss of economic power which might result from the loss of exclusivity. While I recognize the legitimate interests of organized workers in looking after their own welfare, even at the expense of their unorganized brothers and sisters, I do not think society has to weigh organized labor's interests more heavily than the interests of the unorganized workers. Indeed, many unorganized workers have remained in that state for reasons which reflect some sense of societal obligation not to organize, or at least not to use economic weaponry. Should employees who are of that view, or who are under a legal disability which imposes such a view, be put at an economic disadvantage vis-à-vis the rest of their society?

Therefore, while I am not persuaded that my proposal would weaken the overall power of the labor movement, ${ }^{60}$ it is not altogether clear that the weakening of unions would be a bad societal development, insofar as they merely pass additional costs on to unorganized workers.

Another claim for unions is that they have brought some sense of democracy and fair play to the workshop. To the extent that the justification for labor's strength has been its bringing to the individual a sense of participation in his work environment and a sense of being treated fairly, there is at least some inconsistency in an attempt to justify the retention of exclusivity. First, exclusive representation deprives many individuals of the representative they want, certainly an antidemocratic notion when applied to individual grievances. Second, the concepts of fair play and of protecting individual interests may

${ }^{60}$ If exclusivity were abandoned, there might be a realignment of the employees' allegiances to various unions, but I am not clear that the overall strength of the labor movement would be less. 
be better served by doing away with exclusivity and giving every employee the right to select his or her own representative with whom the employer would be required to bargain.

\section{2. "Undesirably" Homogeneous Groupings}

To this point, I have addressed what is the most common argument to support the idea of exclusivity. In my judgment, other arguments raise problems at least as serious. Perhaps the most complex is the problem raised by the nature of the alliances which groups of employees will make. For example, the skilled workers can be expected to join their own unions, just as we expect them to do today in most Globe elections. ${ }^{61}$ Initially, one might be of the view that this is not necessarily all bad. Indeed, to quite an extent, my proposal would do nothing more than give unskilled employees a choice similar to the one already given skilled workers under the present state of the law, a choice that comes closer to real freedom of choice and representation. However, there is a cost to the unskilled workers if the skilled workers separate from them to a greater extent than they are permitted today. Presumably, skilled workers are prepared to work for their employer only if certain conditions are met. However, their hopes or desires may be greater than what they realize today when an industrial union represents them, and these hopes and desires may be realizable under circumstances different from those existing today. For example, skilled workers may be prepared to work for no less than, say, eight dollars an hour. But they may hope for nine dollars, and might be able to realize that greater salary if they are able to negotiate on their own; the employer could then compensate by offering less to the unskilled workers, who are more easily replaced if they are not satisfied with the employer's pay scale. Under the present state of affairs, with skilled employees merged in collective bargaining units with less skilled or more easily replaced employees, the union may aim only for the eight dollar figure, on the thesis that the skilled employees will be minimally satisfied and more will be left over for the unskilled workers. If one has some concern for the status and rewards of the less able, skilled, or fortunate workers, the consequence I describe should be unsettling.

Candidly, I have no idea to what extent my proposal would result in this kind of pattern. Nor am I sure to what extent the

${ }^{61}$ Globe Machinery \& Stamping Co., 3 N.L.R.B. 294 (1937). 
present status of industrial collective bargaining has already capitulated to the apparently increasing insistence of skilled workers to be more adequately represented by industrial unions, although this capitulation by the unions must result, to some extent, in a reduced effectiveness of the representation given the less skilled employees. ${ }^{62}$ It may be that some skilled workers have already exacted from the industrial unions a price close to what would occur under the nonexclusivity proposal.

Moreover, it is not clear that all skilled workers would stick together. While it appears to be true that skilled workers usually opt for separate representation when they are given the chance under present law, the choices these employees currently have are very limited: the industrial union or the craft union, either of which will have to represent a unit. Given a broader choice of alternatives, skilled employees might well split their allegiances in more diverse ways. Indeed, depending on the factors involved in making an individual choice of representative, it is entirely conceivable that there would be situations in which skilled and unskilled workers would continue to find themselves represented by the same union. This is especially true under my proposal, since the less skilled workers are free to select the union which traditionally has represented skilled workers only.

Another type of split among the employees that might be encouraged by my proposal is one along racial lines. Having always subscribed to the ethic that racial separation is not a good thing, I am unsettled about extending the practice of segregation in our society. On the other hand, the competing value of relatively more freedom of choice, especially if it is somewhat informed, cannot be ignored. The fact that unions deal with job opportunities and economic success, facets of life which probably generate unique intensity of feeling, supports the idea of freedom to select one's own union, even if racial considerations, rightly or wrongly, are predominant. One should not be deceived into thinking that employees generally understand or even know about all the factors that we (the "rational" people) would take into account before deciding whether or not to join a union.

${ }^{62}$ See note 49 supra. While the interpretation given article $19, \S 3$, of the UAW constitution emphasized the interests of the overall unit, there can be little question that the authorization of a separate vote for skilled employees highlights their interests. In the long run, such treatment can only come at the expense, to some extent, of the production (nonskilled) workers. 
But they do know something. And they have their biases and prejudices which they should be able to indulge just like the rest of us. Nor can one ignore the fact that the biases may be accurate. The black employees' views that they are being discriminated against may be valid, although unprovable. Moreover, the presence of several unions should provide employees more information about their choices for representation than they receive under the present system. To that extent, a choice based on racial considerations becomes more rational (in the two senses, at least, of informed choice and of eradicating perceived racial discrimination). It would be my hope that, as the competing unions perform, employees would grow away from such racial choices, as other factors take on more importance to the employees and the racial factor less. ${ }^{63}$

\section{Seniority}

It is generally agreed that one of the most important contributions made by the labor movement and collective bargaining to the welfare of employees is the seniority system, which gives employees job security free of arbitrary employer whim or bias. As long as a union represents all of the employees who compete for like or similar jobs, it is an easy task to create a consistent seniority system which works well for all concerned. While the basis for seniority (plantwide versus department versus particular job) and the application of seniority (layoffs, recalls, transfers, promotions) may vary, the fact that the union today usually represents all of the employees in the relevant competing pool makes it possible to reach a single seniority ladder which applies to those employees. Would it be possible to retain such a seniority ladder under my proposal?

If the proposal were adopted, there would almost certainly be changes in the ways seniority ladders were created. One possibility would be to allow each union the opportunity to negotiate its own seniority ladder. The problem with such a solution, of course, is that at first blush there would be no basis for deciding which ladder was the relevant one for making the next

${ }^{63}$ Parenthetically, perhaps, nothing in the proposal should be read to suggest a change in the requirements of Title VII of the Civil Rights Act of 1964, 42 U.S.C. $\S \S 2000 \mathrm{e}$ to e-15 (1970), as amended, 42 U.S.C. $\$ \S 2000 \mathrm{e}$ to e-17 (Supp. II, 1972), which would preclude employers from discriminating on the basis of race in their dealings with employees, and would similarly preclude unions from discriminating with regard to membership. 
layoff, recall, promotion, or transfer. Since that would be a very difficult situation, one hazards the guess that, somehow, the various seniority ladders would have to be reconciled. One possible method to deal with the problem would be to have the firstin-time contract with one union set the pattern for all relevant seniority ladders contained in later contracts with other unions. That first contract would tie the employer to a certain type of seniority scheme which he would not be free to abandon without the first union's consent. The problem with this solution, of course, is that the first union would, in effect, be negotiating a contract for all the employees, not just those it represented. This would constitute a throwback to exclusivity, but it would be less appropriate than the present system because that union might not represent a majority, or even a plurality, of the affected employees. Moreover, such a scheme would encourage employers to attempt to buy off an otherwise weak union with the promise that it would be setting the seniority for all the employees, and thereby be protecting its own at the expense of other employees, who belong to stronger unions.

Another possible response to the dilemma caused by the needs for seniority would be some sort of coalition bargaining. The nature of the marketplace, one can speculate, would push together the unions to negotiate seniority when there was no rational distinction between the work performed by members of each union. To the extent the unions did not voluntarily cooperate with each other, a problem of the sort mentioned in the last paragraph might occur at first: The employer could appeal to unions (or unrepresented individuals) with the claim that the seniority issue offered a chance for gain over rivals. It is not clear that such a consequence would be final, because the employer might well be placing itself in an impossible bind if it attempted to woo unions on the basis of a favorable seniority scheme; it might subsequently find itself faced with a stronger union demanding a different ladder. The employer would be left with the undesirable choice of either breaking the first contract and paying the consequences, or defying the strong union and paying the cost of economic coercion. Faced with such a potential dilemma, the employer might well desire some sort of coalition bargaining, or at least peace with the stronger unions, which would then be making the decision, as a practical matter, on the issue of seniority. (This result is not unlike what is done 
today; the stronger elements within an exclusive representative presumably have the biggest voice on this issue).

While I am speculating again, it seems that both the employer and the unions would desire some sort of uniformity (much akin to today's seniority ladders) and that their mutual desires would most likely produce such a result through some sort of coalition bargaining. ${ }^{64}$

\section{Multiplicity in Negotiations}

Finally, there is considerable concern expressed for the plight of the employer who will be faced with the ordeal of dealing with a number of unions and all that entails: more negotiating sessions, more grievance proceedings, more strikes or threats of strikes, and more competition among the several unions. This concern may not be universal, because there seem to be a number of employers today who desire to deal with as many unions as possible. I am unaware of any evidence that such employers are unduly burdened by the presence of several craft unions, rather than une industrial union. ${ }^{65}$ Moreover, there is no significant evidence that these employers suffer more inefficiency due to strikes. Finally, if it is correct that employee dissatisfaction with the collective bargaining agent is often the cause of wildcatting and other conscious and unconscious concerted acts which result in lower efficiency, there would be considerably less of that sort of "bad" behavior under the proposed system. In terms of efficiency, the result might be a net gain.

Nevertheless, it is not implausible to believe that the proposal might result in less efficiency for some employers and their

${ }^{64}$ While the seniority problem is highlighted in the text because it seems most important, it is really a symptom of a more broadly stated objection to the proposal: uniformity and coordination are needed for some aspects of working conditions. For example, it would be unthinkable in some circumstances for an employer to be forced to grant a series of coffee breaks to different employees at different times. Under the proposal, the solution to this problem and others like it would have to be reached in much the same manner suggested in the text.

${ }^{65}$ It is true, however, that the proposal might complicate matters even for large employers currently dealing with several unions. Today, such an emplover deals with a discrete number of unions for a like number of units. Under the proposal, the employer would have to deal with each of a number of unions (possibly more) over the several different types of jobs and employees in the plant. To that extent. multiplicity would be a problem even for employers already dealing with several unions. Whether it would involve more negotiations for such employers, however. is problematic. 
businesses, while not having such an impact on others. While it is speculation, small employers will probably be more likely to find the multiple negotiations a serious burden. Insofar as these employers compete only among themselves, the impact may not be great. If they compete with significantly larger employers, it is conceivable that negotiating with several unions may have a serious impact on them.

In some ironic way, this objection is the reverse of the "solidarity forever" concern. Unions can be expected to object to the proposal because the loss of claimed unity will hurt vis-à-vis the employer. Some employers may object because the inefficiency of several negotiations will result in greater concessions to reduce the time committed to negotiations, thereby strengthening unions vis-à-vis employers. Can it be both ways?

The answer is probably yes, but only in overall terms. That is, some employers may gain by the apparent loss of employee unity, while other employers may lose because of the multiplicity of unions, negotiations, and grievances. Whether the present apportionment produced by exclusivity is better than the distribution that would result from nonexclusivity is something I find incalculable.

\section{ConcLusion}

On balance, it is not clear to me that the possible drawbacks of abandoning the exclusive representation model for collective bargaining in our country would outweigh the benefits which would result. The proposal would give individual workers considerably more protection to vindicate their own individual interests. In the process, it is possible-perhaps likely-that unions would be more democratic, collective bargaining would at least deal with more of the employees' problems and desires, unions would be more responsive to individuals' grievances, and, incidentally, the National Labor Relations Board would be relieved of its election responsibilities. While there appear to be many possible drawbacks to the proposal, one can be sure neither of their likelihood nor of the extent of their impact upon legitimate interests affected by the labor laws. Hopefully, this Article has at least made the idea of nonexclusive collective bargaining something reasonable and worthy of further exploration. 